\title{
EFFECT OF RE-OPENING OF A MIGRATORY PATHWAY FOR EEL (ANGUILLA ANGUILLA, L.) AT A WATERSHED SCALE
}

\author{
C. BRIAND (1), D. FATIN (1), G. FONTENELLE (2), E. FEUNTEUN (3).
}

(1) Institution Aménagement de la Vilaine, 56130 La Roche-Bernard, France.

(2) Agrocampus-Rennes, Département Halieutique UPR MESH, 65, rue de St-Brieuc, 35042 Rennes Cedex, France.

(3) Laboratoire de biologie et d'environnement marin, Université de La Rochelle, 17042 La Rochelle Cedex, France.

Reçu le 10 novembre 2004

Accepté le 10 février 2005

Received November 10, 2004

Accepted February 10, 2005

\begin{abstract}
The construction of the Arzal dam eel ladder in 1996 allowed enhancing fluvial recruitment from a negligible level, limited to yellow eels crossing sluice and dam overflow, to a level ranging from 0.2 to 2.4 million glass eels per year. The effect of such recruitment on the eel population (Anguilla anguilla) of the Vilaine watershed was analysed at 19 electrofishing sampling stations. From 1998 to 2003 , average densities of eel varied from 0.34 to 0.72 eels. $\mathrm{m}^{-2}$, with a maximum reached in 1999 of 0.82 eels. $\mathrm{m}^{-2}$. Fluvial recruitment failure, together with density dependent mortalities, explains the drop in yellow eel densities observed from 1998 in the downstream area $(<50 \mathrm{rkm})$ and from 2000 in the middle stream area (50$100 \mathrm{rkm}$ ). The largest densities consisted of a large proportion eels classified as age 1 and the increased density in middle stream sectors was interpreted as the consequence of density-dependent migration at the periphery of a saturated area. The construction of 13 eel ladders on the Vilaine waterway in 1999 and 2000 was followed by increased densities in the upstream area $(>100 \mathrm{rkm})$ in 2001 . The comparison to an electrofishing survey performed at 17 stations in 1981, ten years after dam construction, confirmed that ladder installation increased densities by a factor 6 and modified the population structure, with densities of eels age 0 and 1 multiplied 29 fold. This change corresponded to reduced escapement rates to the glass eel fishery (1\% to $5 \%$ ). Considering this result, a preliminary escapement target of 240 glass eel per $\mathrm{km}^{2}$ of watershed area or 1500 glass eel per ha of water surface, is proposed and discussed for glass eel fisheries.
\end{abstract}

Key-words: Electrofishing, density dependence, colonisation, mortality, fishery management.

\section{EFFET DE LA RÉOUVERTURE D'UN AXE MIGRATOIRE POUR L'ANGUILLE (ANGUILLA ANGUILLA, L.) À L'ÉCHELLE D'UN BASSIN VERSANT}

\section{RÉSUMÉ}

La construction de la passé à anguille d'Arzal en 1996 a permis d'augmenter les passages de la passe d'Arzal, d'un niveau quasi nul, limité aux anguilles passant au travers de l'écluse et des surverses du barrage, à un niveau variant entre 0,2 et 2,4 millions de civelles par an. L'effet d'un tel recrutement sur la population d'anguilles (Anguilla anguilla) 
du bassin versant de la Vilaine, a été analysé sur 19 stations de pêche électrique. De 1998 à 2003 , les densités moyennes d'anguille ont varié de 0,72 à 0,34 anguilles. $\mathrm{m}^{-2}$, avec un maximum atteint en 1999 à 0,82 anguilles. $\mathrm{m}^{-2}$. La baisse du recrutement fluvial, et des mortalités densité dépendantes, expliquent la chute des densités d'anguilles observées à partir de 1998 dans la zone aval (<50 rkm) et de 2000 dans les zones intermédiaires (50-100 rkm). Les densités les plus fortes ont correspondu à une forte proportion d'anguilles classifiées comme étant d'âge 1, et l'augmentation constatée dans les secteurs intermédiaires a été interprétée comme la conséquence d'une migration densité dépendante à la périphérie d'une zone saturée. La construction de 13 passes à anguilles a été suivie par une augmentation des densités dans la zone supérieure (> $100 \mathrm{rkm}$ ) en 2001. La comparaison au suivi historique de 1981, dix ans après la fermeture du barrage, a permis de confirmer que l'installation de la passe à anguille d'Arzal s'est accompagnée d'une augmentation d'un facteur 6 des densités et d'un bouleversement de la structure de population avec les densités d'anguilles d'âge 0 et 1 multipliées par 29. Ce changement a correspondu à des taux d'échappement de 1 à $5 \%$ de la pêcherie civellière. Considérant ce résultat, une cible préliminaire d'échappement, à 240 civelles par $\mathrm{km}^{2}$ de surface de bassin versant, ou à 1500 civelles par ha de surface en eau, est proposée et discutée pour les pêcheries civellières.

Mots-clés : Pêche électrique, densité - dépendance, colonisation, mortalité, gestion des pêcheries.

\section{INTRODUCTION}

In the genus Anguilla (Schrank 1798), spawning takes place in the deep ocean, more precisely, at salinity fronts in tropical eastward flowing currents (AOYAMA, 2003). From the spawning area, the leptocephalus larvae are transported to continental shelf waters, where they metamorphose into glass eels (TESCH, 2003; TZENG, 2003). Glass eels next colonize continental and coastal waters through the use of coastal currents and selective tidal stream transport (STST) (MCCLEAVE and WIPPELHAUSER, 1987), allowing transport from the continental slope to estuaries at a minimum energy cost (WILLIAMSON, 1987; WIPPELHAUSER and MCCLEAVE, 1987). In the estuaries, STST will concentrate glass eels at a point, defined by tidal and fluvial currents, where STST is no longer effective (GASCUEL, 1987). In the springtime, with increasing temperatures, STST by glass eels will shift towards a more rheotactic colonisation (GASCUEL, 1986). This behaviour leads to the gathering of large number of glass eels near banks (VILTER, 1944; BERTIN, 1951) but only lasts a short while and leads to the diffusion and settling of glass eels in or close to the estuarine areas.

Most of the colonization process of continental waters is the result of migration at the yellow eel stage (LEGAULT, 1986; MORIARTY, 1986; WHITE and KNIGHTS, 1997). The migrating behaviour of individual eels is variable, with migration range scaling from local movements (BAISEZ, 2001) to long-range migrations of several hundred kilometres (LEGAULT, 1996). However, when looking at the population level, the overall picture is one of random movements, driven by density-dependent factors, which explains the negative exponential distributions of eel densities from the estuaries to the upper reaches of rivers, similar to those obtained from modelling random movements from a diffusing source (SMOGOR et al., 1995; IBBOTSON et al., 2002).

The effect of varying recruitment levels and density-dependence on the colonization process is still poorly understood. The main reason is that colonization is the result of changes in population pressure within a given site, a dynamic process, including immigration, emigration and growth, (LOBÓN-CERVIÁ et al., 1995; FEUNTEUN et al., 2003). To understand this dynamic, eel behaviour can be studied at the experimental level (KNIGHTS, 1987; GLOVA, 2001; GLOVA, 2002). Local population dynamics can also be 
measured in short rivers allowing the measurement of inputs and outputs from a system as well as in-stream densities (VØLLESTAD and JONSSON, 1988; FEUNTEUN et al., 2000). Finally, historical changes can be recorded at a larger scale, through the repeated monitoring of eel densities in large basins (APRAHAMIAN, 1988; APRAHAMIAN, 2000). The steep decline in glass eel catches observed since the 1980's (MORIARTY and DEKKER, 1997) has brought forward the question of the effect of declining glass eel recruitment on yellow eel populations and the overall picture is a decrease in the range of eel populations. At the local level, decreases in glass eel numbers will be accelerated by commercial exploitation that occurs in most estuaries on the Atlantic coast (CASTELNAUD, 2000), and also by habitat degradation and dams that restrict access to upstream river areas.

In the Vilaine watershed, the construction of an eel ladder in 1996 at the Arzal estuarine dam offers the opportunity to observe a reverse trend: the recolonization of a freshwater basin. Indeed, before construction of the ladder, only yellow eels only yellow eel and a limited number of glass eel were able to pass the dam, and an electrofishing survey conducted in 1981 demonstrated the effect of the Arzal dam on the watershed eel stock (ELIE and RIGAUD, 1984). This paper aims at (1) analysing historical change by comparing 1981 and 1998-2003 eel populations, (2) analysing re-colonization trends, using eel size and age structures in order to describe density-dependent processes, (3) relating in-stream eel densities, evaluated by electrofishing surveys on tributaries within the watershed, to fluvial recruitment monitored on an eel ladder, and finally addressing the glass eel fisheries management issue.

\section{MATERIAL AND METHODS}

\section{Site description}

The Vilaine watershed covers $10400 \mathrm{~km}^{2}$. Slopes range from $5 \%$ at the source of the river (146 meters high) to 0\% near Redon (ELIE and RIGAUD, 1984). Most of its tributaries are lowland streams with slow current, macrophytes, and a fine gravel substrate. The schistose substratum is associated with impermeable soils and causes important flow variations, with severe floods in winter and low waters in summer. The two main rivers are the Vilaine and the Oust. They are waterways fitted out with dams whose heights are 2 to $5 \mathrm{~m}$ (Figure 1). The first navigation dams are found at a distance of 45 river kilometres (rkm) for the Oust and $70 \mathrm{rkm}$ for the Vilaine. Weirs with gentle slopes more easily crossed by eels occur on several tributaries.

For this study, the watershed was separated into three distance classes. The downstream area $(<50 \mathrm{rkm})$ is formed mainly of tributaries connected to the sea-level freshwater reach located upstream from the Arzal dam. It forms a large river (30-150 m width), with marshes in the downstream area of tributaries.

The middle stream area consists of sectors located from 50 to $100 \mathrm{rkm}$ from the Arzal dam. The tributaries sampled during this study were the Canut Sud River, separated from the main stream by one dam and the Aron brook, accessible after two dams. The third, the Arches Brook, was far more difficult for eels to access. It was located on the Oust River and separated with 6 navigation dams from the downstream water body. As those dams were equipped with eel ladders only in 2003 , a colonization effect was not visible during this study.

The upstream area was on tributaries connected to the Vilaine waterway, located from 110 to $165 \mathrm{rkm}$ from the Arzal dam. In 1999 and 2000, 13 eel ladders were constructed on the Vilaine allowing migration to the Canut Nord and the Chèze tributaries. They also facilitated access to the Chevré tributary, although three dams remained unequipped for access to this river. A ladder located on the second dam was washed away during a flood in the winter of 2000. 


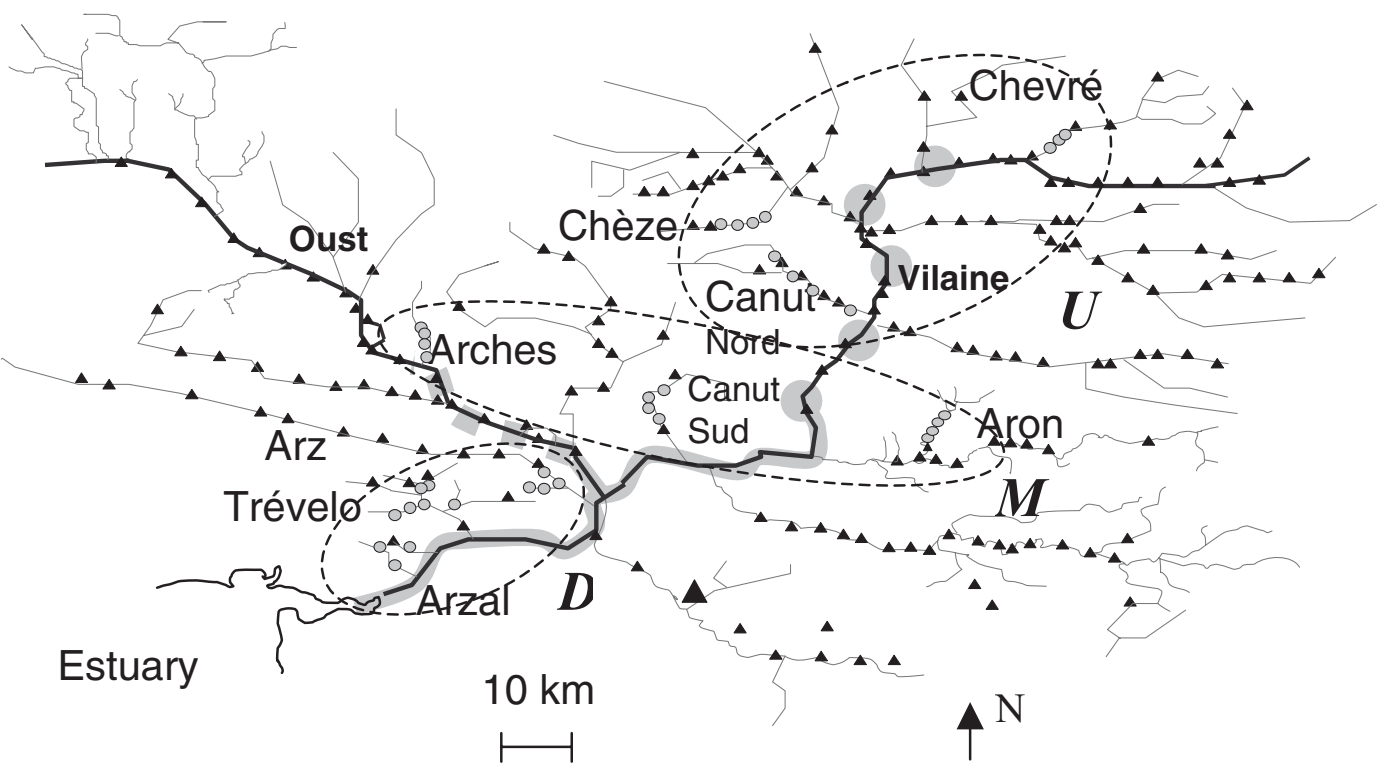

Figure 1

Map of the Vilaine watershed, 1998 to 2003 monitoring. $D=$ Downstream area $<50 \mathrm{rkm}, M=$ Middle stream area $50-100 \mathrm{rkm}, \mathrm{U}=$ Upstream area $>100 \mathrm{rkm}$, $\Delta=$ dams, $\bullet=$ electrofishing station, gray line $=$ sector equipped with eel ladders in 1996, grey circles along the Vilaine waterway $=2001$, grey dotted line along the Oust waterway $=2003$.

Figure 1

Carte du bassin versant de la Vilaine, suivis 1998 à 2003. $D=$ zone aval $<50 \mathrm{rkm}$, $M=$ zone intermédiaire $50-100 \mathrm{rkm}, U=$ zone amont $>100 \mathrm{rkm}, \Delta=$ barrages, - = station de pêche électrique, ligne grisée = secteur équipé de passe à anguille en 1996, cercles grisés le long de la Vilaine $=2001$, pointillés grisés le long de l'Oust $=2003$.

\section{Estuarine recruitment}

The Arzal dam was built in 1970 in the estuary, $12 \mathrm{~km}$ from the sea. While its initial design was aimed at reducing the floods in the nearby towns, by blocking the tide entry, it was decided that it should remain open to allow penetration of the incoming tide. However, the construction of a drinking station led to closure of the gates, and the dam now concentrates glass eels over a few hundreds of meters downstream where a commercial glass eel fishery operates. Escapement from this fishery is very low and eels that recruit upstream tend to be those arriving after the fishing season (BRIAND et al., 2003). Since 1998, management measures were introduced to reduce the length of the fishing season.

\section{Fluvial recruitment}

A Fish-Pass-style glass eel trapping ladder was constructed in 1995. It is made of two inclined panels-composed of tufts of synthetic bristles (LEGAULT, 1992) located on each side of a pooling pass. From 1996, it was monitored daily during spring and weekly when catches were low. A net separated glass eels from young eels. Glass eels were weighed and the average wet weight was measured after draining and used to calculate the number of glass eels. Yellow eels were counted. Experimental fishing was also conducted in the estuary in 1999, 20002002 and 2003 and the corresponding number 
of glass eels transported upstream from the Arzal dam was similarly calculated from wet weight.

\section{Electrofishing}

Nineteen electrofished stations located on 10 tributaries were prospected in autumn from 1998 to 2003 (Figure 1). They corresponded to sectors of low width (mean = $3.72 \mathrm{~m}$, $\mathrm{SD}=1.89$ ) and depth (mean $=0.22 \mathrm{~m}, \mathrm{SD}=0.12$ ) and a surface area of about $120 \mathrm{~m}^{2}$ $\left(\right.$ mean $\left.=122 \mathrm{~m}^{2}, \mathrm{SD}=42\right)$. Each section was enclosed with $3 \mathrm{~mm}$ mesh stop nets and sampled by two consecutive passes with a "Heron" ${ }^{\mathrm{TM}}$ " electrofishing equipment (200-700 V, DC, 1-4 A). The point sampling method was applied: a fishing effort of at least 30 seconds on areas of $3 \mathrm{~m}^{2}$ (FEUNTEUN, 1994). The use of direct current ensured the best efficiency because of a reduced tetanizing effect (LAMARQUE, 1976; COWX and LAMARQUE, 1990). Depending on river width, one to four people collected fishes downstream of the anode with hand nets $(1.3 \mathrm{~mm}$ mesh size). Eels were measured to the nearest $\mathrm{mm}$ and weighed to the nearest $\mathrm{g}$.

Electrofished sectors were often located on aprons (low depth and high velocity sectors). As the watershed slopes gently, aprons form only a little part of total water surface of tributaries. This choice has probably biased the size structure and density of the eel population, as young eels $<300 \mathrm{~mm}$ concentrate in shallow and high flow velocity sectors (LAFFAILLE et al., 2003). These sectors were also those where aquatic vegetation was the most abundant, providing both shelter and foraging area (LAFFAILLE et al., 2003). As a consequence, relative to the whole eel population of the watershed, sampling was inaccurate, and provided mostly eels of small size. However, the focus on sectors of reduced width and depth, with good transparency guaranteed good efficiency (ZALEWSKI and COWX, 1990) and enabled a relative estimation, reliable for inter-annual comparison of size-structure and densities of young eels.

Seventeen stations, electrofished for eel in 1981 were added to test temporal variation (ELIE and RIGAUD, 1984). Those sectors were located in the same tributaries as those chosen in 1998 but were of a larger size, from 172 to $1100 \mathrm{~m}^{2}$. Sections were enclosed with nets and sampled with 2 to 4 consecutive passes.

\section{Density and size structure}

Fish abundance was estimated using the "De Lury" method (COWX and LAMARQUE, 1990). Densities were calculated from station surface areas. For each station, biomass was calculated as follows, $B_{\text {est }}=B^{*} N_{\text {est }} / N$, with $N_{\text {est }}$ and $B_{\text {est }}$ being the estimated density and biomass, and $\mathrm{N}$ and $\mathrm{B}$ the total number of eels and the biomass caught during the two passes. Density per length class $\mathrm{N}(\text { size })_{\text {est }}$ of $10 \mathrm{~mm}$ was extrapolated linearly from total estimated densities and size structure $\mathrm{N}(\text { size })_{\text {est }}=\mathrm{N}(\text { size })^{\star} \mathrm{N}_{\text {est }} / \mathrm{N}$. The electrofishing efficiency was calculated as the percentage of eels, which were caught in the first sweep as a proportion of the total estimated population size determined when the survey was finished (ZALEWSKI and COWX, 1990).

\section{Age classification}

The age structure was calculated from samples collected and validated at two different periods. The first samples were collected in freshwater in 1989 and 1990 (MOUNAIX, 1992). Additional samples were collected from 1997 to 1999. The sectors they came from were chosen apart from those sampled during the inter-annual survey, in order to avoid any side effect on eel density such as put forward by BARAK and MASON (1992) (Figure 2).

As the variation from 1989 to 1999 was not significant, size-age data corresponding to the two periods were pooled. From 164 eels sampled, 153 provided an adequate ageing (MOUNAIX and BRIAND, unpublished results) (Table I). 


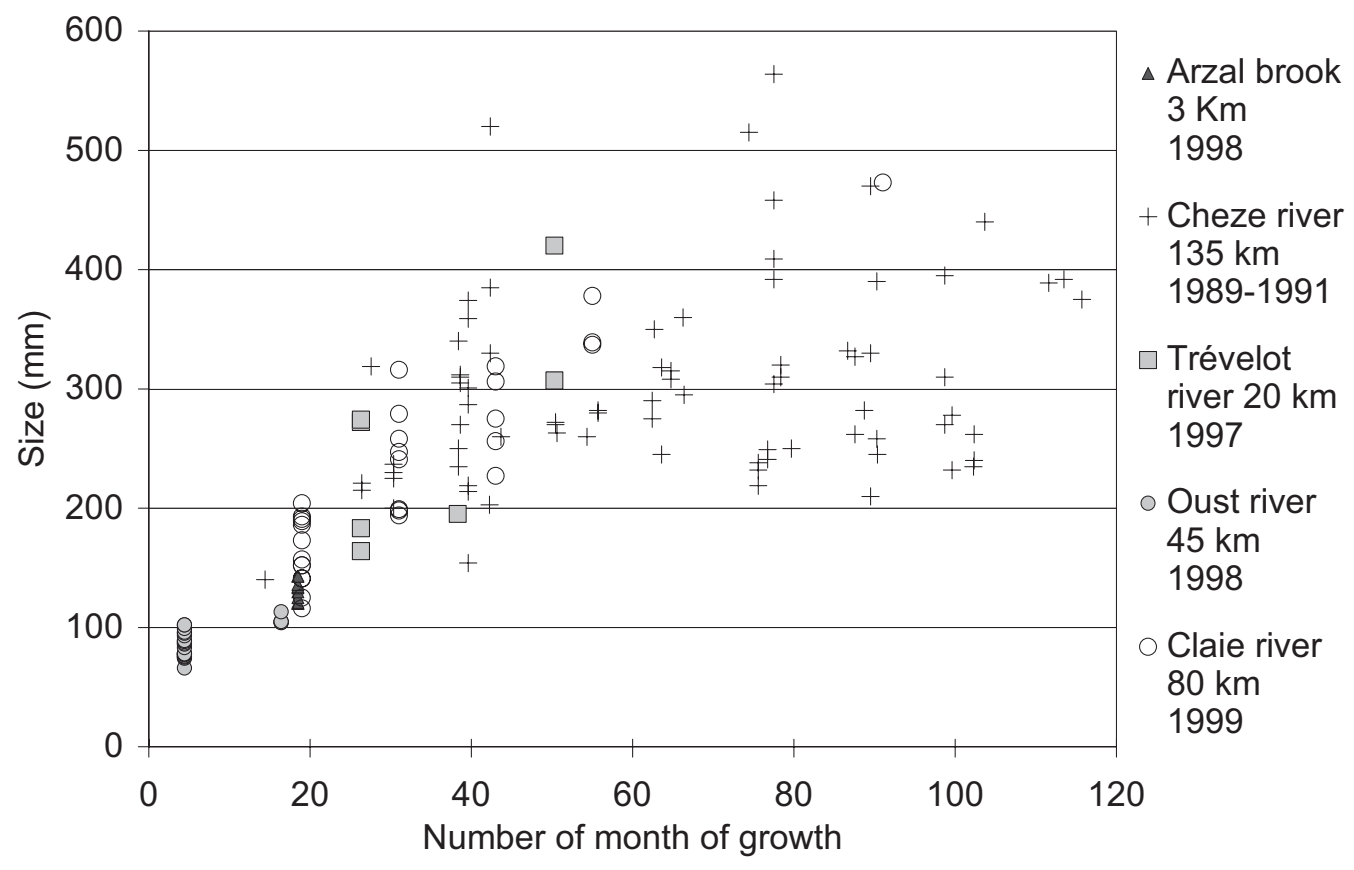

\section{Figure 2}

Sizes of eels as a function of time in months. Eels were collected from several sectors from 1989 to 1999.

\section{Figure 2}

Taille des anguilles en fonction de la durée en mois. Les anguilles ont été collectées sur plusieurs secteurs de 1989 à 1999.

\section{Table I}

Size characteristics of eels aged 0 to $4+$ collected in the Vilaine watershed from 1989 to 1999.

\section{Tableau I}

Caractéristiques de taille des anguilles âgées 0 à 4 + prélevées sur le bassin versant de la Vilaine de 1989 à 1999.

\begin{tabular}{ccccc}
\hline Ages & N & Mean $(\mathbf{m m})$ & Range $(\mathbf{m m})$ & SD \\
\hline 0 & 24 & 87 & $66-113$ & 12 \\
1 & 26 & 145 & $104-204$ & 28 \\
2 & 19 & 235 & $164-319$ & 42 \\
3 & 25 & 288 & $154-520$ & 75 \\
$4+$ & 59 & 325 & $210-564$ & 84 \\
\hline
\end{tabular}

The data were then used to build a size-age key. Eels estimated as $\geq$ age 4 were combined into one age class. Length frequencies of each age class were calculated under the assumption of a normal distribution of sizes for a given age. Normal splitting for each age class $\mathrm{N}_{a}(\mathrm{~m}, \mathrm{SD})$ was based on mean and standard deviation calculated from the sample. Per size-age frequency $\left(P_{a}\right)$ was calculated as $P_{a}=N_{a}(m, S D) / \Sigma_{a} N_{a}(m, S D)$ and 
the raw size-age key was transformed as illustrated in Figure 3. For each station, a density per age class $\mathrm{N}(\mathrm{age})_{\text {est }}$ was calculated from density per length class $\mathrm{N}(\mathrm{size})_{\text {est }}$.

The use of the size-age key assumes that growth was not different in 1981 and 1998-2003. Additionally, it was assumed there was an equal weight to different age classes. This is obviously not correct as the age structure varies according to cohort strength and mortality, and these factors possibly modified the respective weight of age classes in the population. But this classification was preferred to an arbitrary size-class grouping because it provided an indication of the age structure.

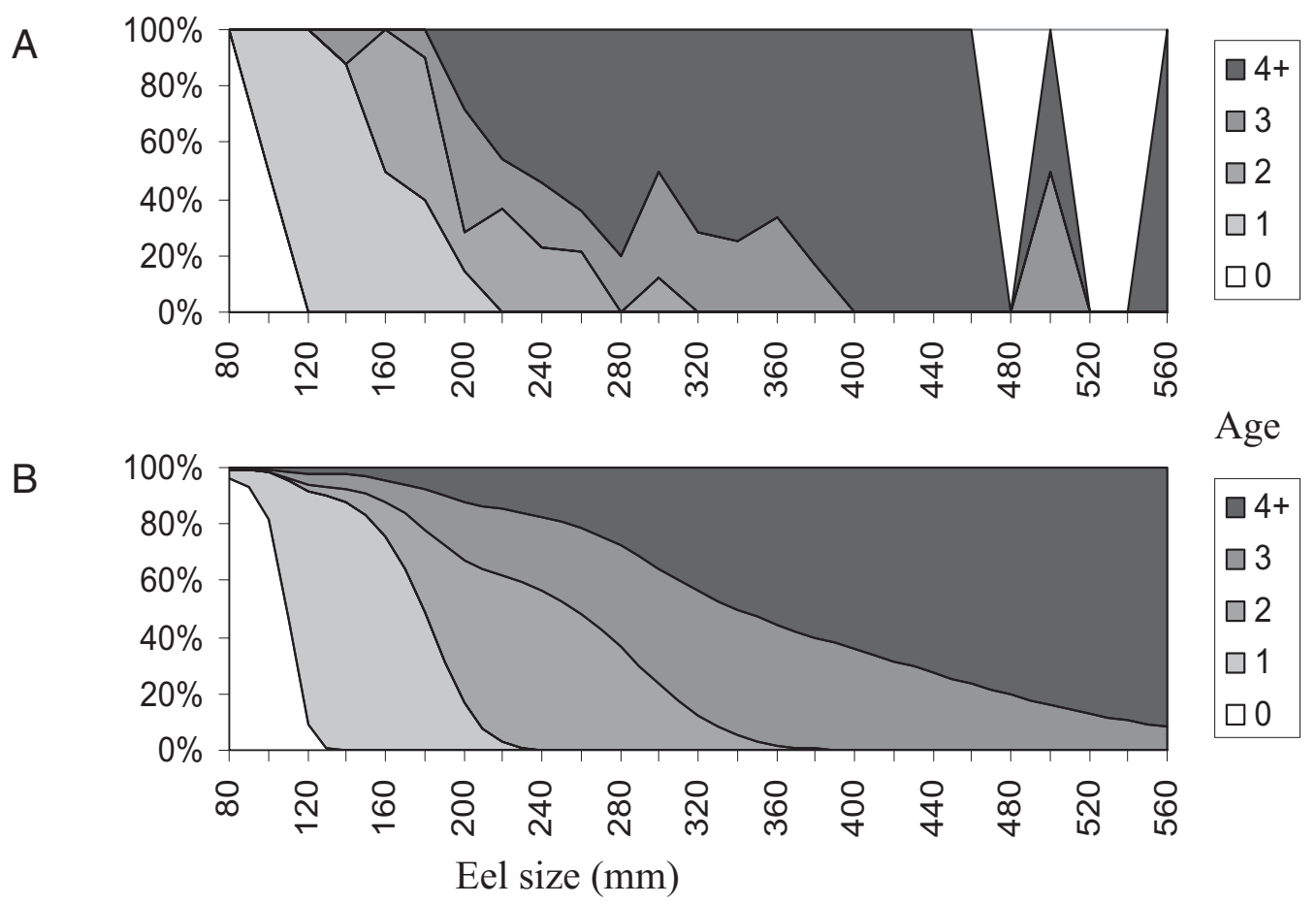

\section{Figure 3}

A) Size-age key based on 164 eels sampled in freshwater on the Vilaine watershed. B) Size-age key based on the same data after a splitting based on the assumption of a normal distribution of size for age.

\section{Figure 3}

A) Clé taille-age obtenue à partir de 164 anguilles échantillonnées en eau douce sur le bassin versant de la Vilaine. B) Clé taille-âge construite sur les mêmes données après redistribution basée sur une distribution gaussienne des tailles aux âges.

\section{Statistical analyses}

Estimated eel densities from 1998 to 2003 were $\log$ transformed $\left(\log N_{\text {est }}+1\right)$ to normalise their distribution. An analysis of variance was then performed using six years and the three distance classes previously described (Figure 1), as categorical factors and log transformed densities as the dependent factor. A Tukey test was next used to compare densities grouped using the factors whose effects were significant.

The age structure evolution from 1998 to 2003 was analysed with Chi-square tests. Tests were performed on the sum of eel estimated densities per age, at 19 stations, and 
for separate distance groups, corresponding to the sampling of 7,6 and 6 stations for groups $<50 \mathrm{rkm}, 50-100 \mathrm{rkm}$, and $>100 \mathrm{rkm}$, respectively. An identical procedure was used to compare 1981 and 1998-2003 grouped data.

Cross correlations were tested between yearly values of fluvial recruitment (19962003) and yearly values of densities per age. Again, the analysis was performed for all stations and for separate distance groups. calculated.

In the following results, tables and figures, 95\% confidence intervals were

\section{RESULTS}

\section{Estuarine recruitment}

The total catches of the fishery have decreased from $57 \mathrm{~T}$ in 1981 to $20.3,21,17.4$, $15.5,14.2,8.2,15.8,8.9 \mathrm{~T}$ for 1996 to 2003 respectively.

\section{Fluvial recruitment}

Recruitment into the watershed was mostly glass eels, varying from 0.22 to 2.47 million per year. Yellow eel counts on the ladder ranged from 6590 to 36886 . The two larger recruitment periods occurred in 1996 and 1998 and the fluvial recruitment decline from 1999 mirrored the decrease in commercial landings from 21 tons in 1997 to 8.9 tons in 2003. Trapping ladder catches diminished rapidly and fishery management measures together with glass eel transport operations probably smoothed the effect of recruitment failure but were not sufficient to maintain fluvial recruitment (Figure 4).

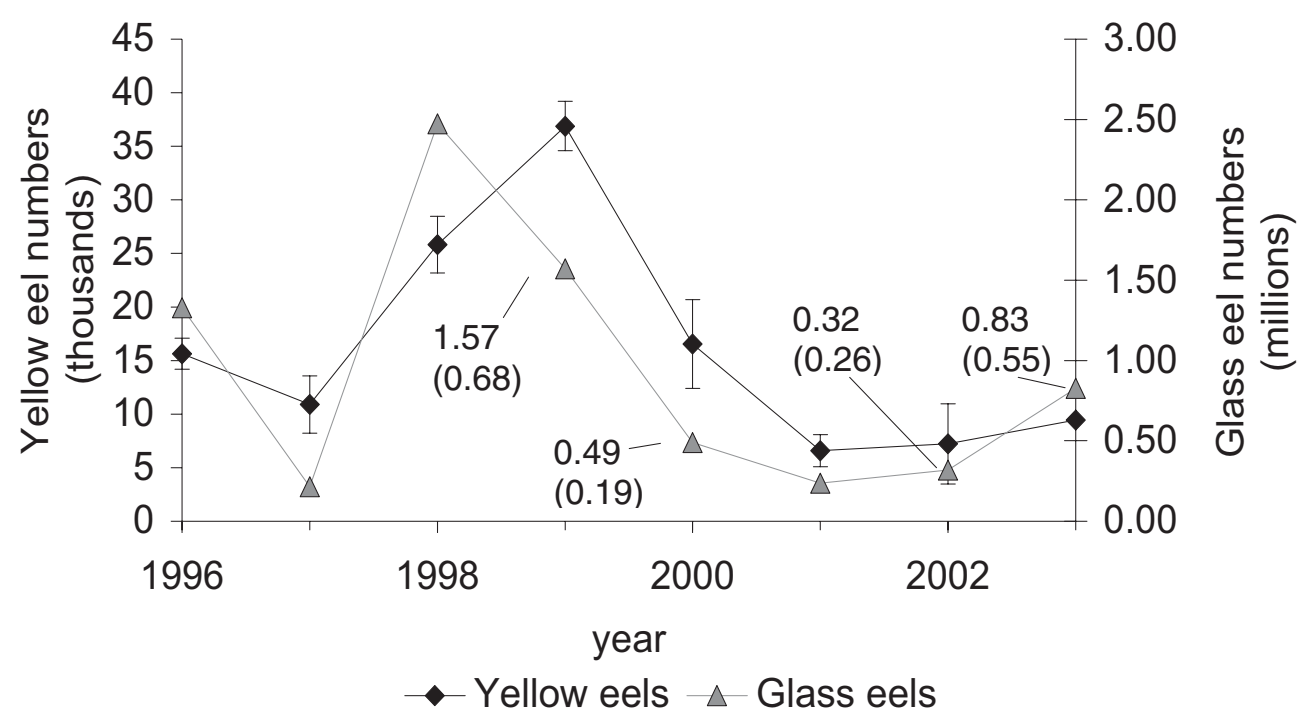

\section{Figure 4}

Historical trend for fluvial recruitment of yellow and glass eels. Values in brackets indicate the number of glass eels fished in the estuary and transported directly to freshwater in the vicinity of the Arzal dam.

\section{Figure 4}

Tendance historique du recrutement fluvial d'anguilles jaunes et de civelles. Les valeurs entre parenthèses indiquent le nombre de civelles pêchées en estuaire et transportées directement en eau douce à proximité du barrage d'Arzal. 


\section{Trend in eel population from 1998 to 2003}

Electrofishing operations allowed the capture of 6270 eels. Electrofishing efficiency varied significantly among years from $69 \% \pm 8 \%$ to $46 \% \pm 10 \%$, Kruskal-Wallis, $N=114$, $p<0.01$ (Table II). It was negatively correlated with densities $(r=-0.22, p<0.05)$ and depth $(r=-0.20, p<0.05)$.

Average densities increased from $0.72 \pm 0.33 \pm$ eels. $\mathrm{m}^{-2}$ in 1998 to $0.82 \pm 0.44$ eels. $\mathrm{m}^{-2}$ in 1999 and then decreased to $0.34 \pm 0.10$ eels. $\mathrm{m}^{-2}$ in 2003 (Figure 5).

Average biomasses were stable between $16 \mathrm{~g} \cdot \mathrm{m}^{-2}$ and $18 \mathrm{~g} \cdot \mathrm{m}^{-2}$ from 1998 to 2001 and decreased to 12 and 9 g.m ${ }^{-2}$ in 2002 and 2003 (Figure 6).

Analysis of variance from 114 log-transformed values of eel densities (model Rsquare 0.37 ) showed that neither temporal factor (years) nor crossed effect (year ${ }^{\star}$ distance) were significant (Table III). The only significant trend was the distance class, with the most distant sites $(>100 \mathrm{rkm})$ having significantly lower densities than the other sites $(<50 ; 50-$ 100 rkm) (Tukey, $\mathrm{P}<0.001$ ).

The density was more correlated with the number of dams $(r=-0.45, P<0.001)$ than with distance $(r=-0.31, p<0.05)$ (Table IV).

\section{Table II}

Variation of eel catches and electrofishing efficiency calculated for 17 stations for 1981 and 19 stations for the period 1998-2003. $\mathrm{N}=$ mean number of eels caught per station, Nest $=$ mean density calculated from De Lury estimates, $E=$ mean electrofishing efficiency, $\Sigma \mathbf{N}=$ total number of eel caught.

\section{Tableau II}

Variation des captures d'anguilles et de l'efficacité de pêche électrique calculée sur 17 stations pour 1981 et 19 stations pour la période 1998-2003. $\mathrm{N}=$ nombre moyen d'anguille capturé par station, Nest $=$ densité moyenne calculée à partir des estimations De Lury, $\mathrm{E}=$ Efficacité de pêche moyenne, $\Sigma \mathrm{N}=$ nombre total d'anguilles capturées.

\begin{tabular}{lccccccc}
\hline \multicolumn{7}{c}{ Years } \\
\hline $\mathrm{N}$ & $\mathbf{1 9 8 1}$ & $\mathbf{1 9 9 8}$ & $\mathbf{1 9 9 9}$ & $\mathbf{2 0 0 0}$ & $\mathbf{2 0 0 1}$ & $\mathbf{2 0 0 2}$ & $\mathbf{2 0 0 3}$ \\
$\mathrm{N}_{\text {est }}\left(\mathrm{N} \cdot \mathrm{m}^{-2}\right)$ & $0.11 \pm 0.07$ & $0.72 \pm 0.33$ & $0.82 \pm 0.44$ & $0.7 \pm 0.27$ & $0.71 \pm 0.26$ & $0.47 \pm 0.18$ & $0.34 \pm 0.1$ \\
$\mathrm{E}(\%)$ & $75 \pm 13$ & $51 \pm 6$ & $46 \pm 10$ & $65 \pm 7$ & $60 \pm 8$ & $56 \pm 11$ & $69 \pm 8$ \\
$\Sigma \mathrm{N}$ & 140 & 1007 & 1196 & 1238 & 1335 & 836 & 658 \\
\hline
\end{tabular}

\section{Table III}

ANOVA conducted on eel densities and two dependent factors, years (1998 to 2003) and distance (< $50 \mathrm{rkm}, 50-100 \mathrm{rkm},>100 \mathrm{rkm})$.

Tableau III

ANOVA portant sur les densités d'anguilles et deux facteurs dépendants, année (1998 à 2003) et distances (< 50 rkm, 50-100 rkm, > 100 rkm).

\begin{tabular}{lrcc}
\hline Source of variation & df & F-ratio & P \\
\hline Year & 5 & 1.55 & 0.18 \\
distance & 2 & 13.9 & 0 \\
year distance & 10 & 1.90 & 0.05 \\
Error & 96 & & \\
\hline
\end{tabular}




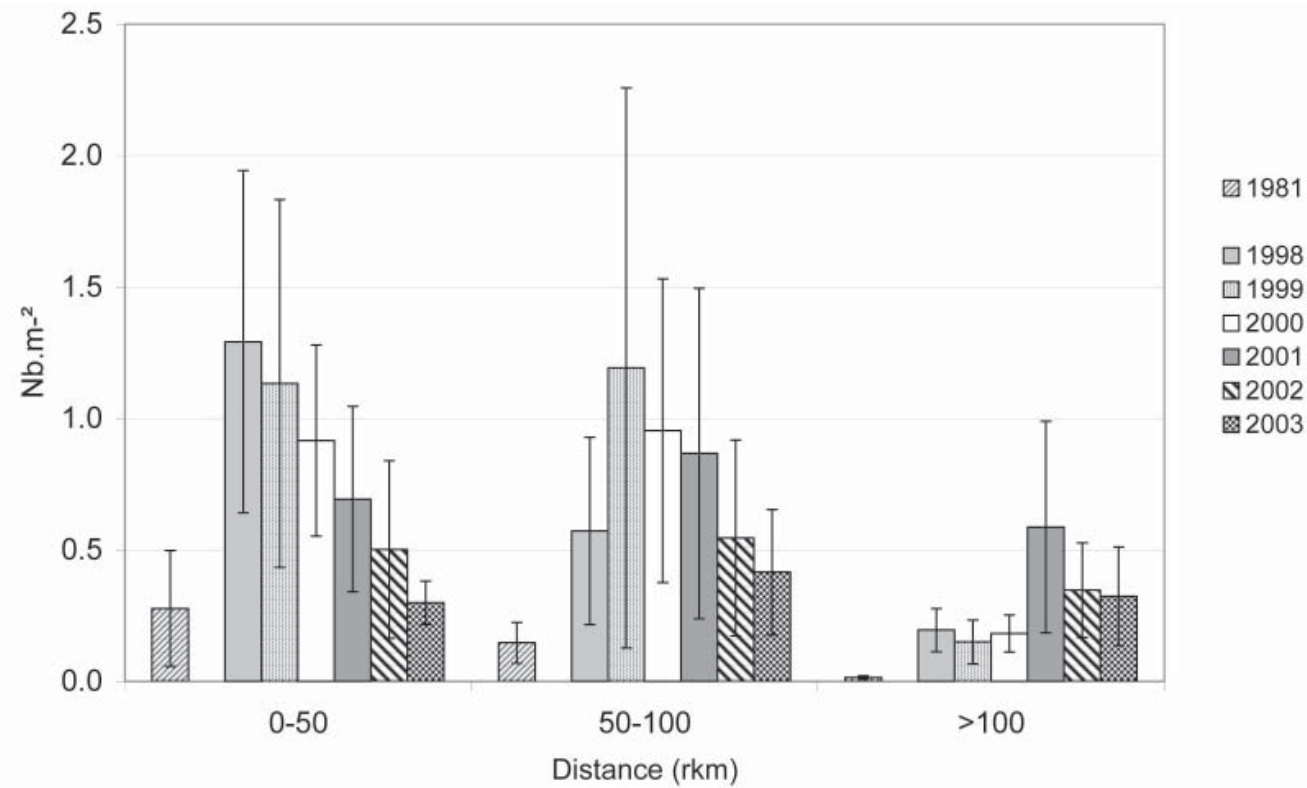

Figure 5

Mean eel densities per distance class for electrofishing operations in 1981 and 1998 to 2003.

\section{Figure 5}

Densités moyennes d'anguilles par classe de distance pour les pêches électriques de 1981 et de 1998 à 2003.

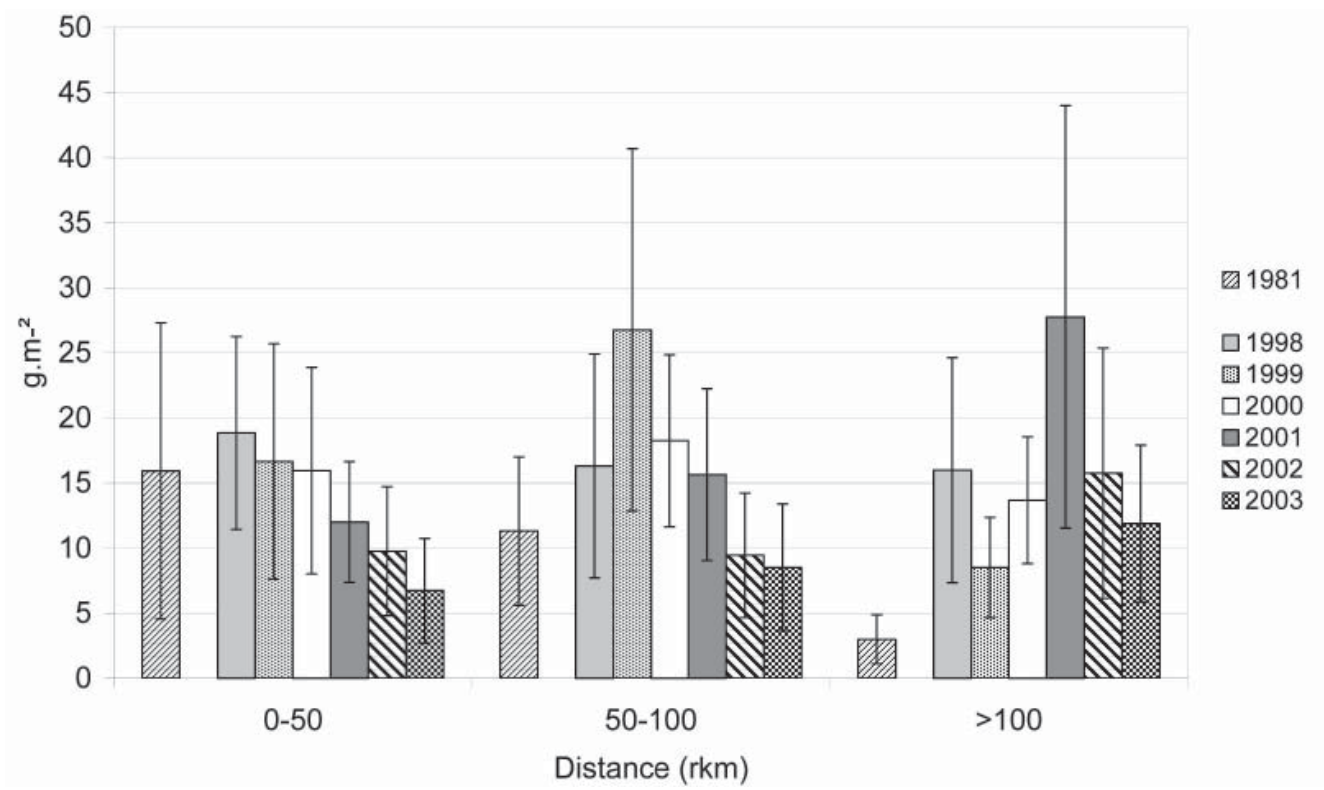

Figure 6

Mean biomasses of eels per distance class for electrofishing operations in 1981 and 1998 to 2003.

Figure 6

Biomasses moyennes d'anguilles par classe de distance pour les pêches électriques de 1981 et de 1998 à 2003. 
There was a yearly dependence in cumulated densities per age $(\mathrm{N}=7056, \mathrm{df}=20$, $\mathrm{p}<0.001$ ) (Table V). This dependence was also observed when looking at the cumulative densities in the lower $(\mathrm{N}=3383$, $\mathrm{df}=20, \mathrm{p}<0.001)$, middle stream $(\mathrm{N}=2607, \mathrm{df}=20$, $\mathrm{p}<0.001)$ and upstream areas $(\mathrm{N}=1066, \mathrm{df}=20, \mathrm{p}<0.001)$. This dependence indicated a shift in age composition from 1998 to 2003 for the three distance classes.

\section{Comparison with 1981 reference data}

In 1981, seventeen electrofishing operations captured 140 eels. Mean densities were $0.11 \pm 0.07$ eels. $\mathrm{m}^{-2}$ but densities were lower in the upstream area at $0.02 \pm 0.004$ eels. $\mathrm{m}^{-2}$ (Table II, Figure 5). The density was lower in 1981 than in 1998-2003 (Mann Whitney test, $\mathrm{N}=131, \mathrm{p}<0.001$ ) and the age structured densities differed between the two periods (Chi Square test, $\mathrm{df}=4, \mathrm{P}<0.001)$.

Mean biomasses were lower than 1998-2003 records in the upstream area $(3 \pm 2 \mathrm{~g}$. $\mathrm{m}^{-2}$,), but were similar to 1998-2003 in the downstream $\left(16 \pm 11 \mathrm{~g} \cdot \mathrm{m}^{-2}\right)$ and middle stream areas $\left(11 \pm 6\right.$ g.m $\left.{ }^{-2}\right)$ (Figure 6).

\section{Table IV}

Correlations for 19 stations sampled from 1998 to 2003 on the Vilaine watershed and associated Bonferroni probabilities.

Tableau IV

Corrélations pour 19 stations échantillonnées de 1998 à 2003 sur le bassin versant de la Vilaine et probabilités de Bonferroni.

\begin{tabular}{lcc}
\hline & Distance to estuary & Number of dams \\
\hline Age 0 & $-0.43(<0.001)$ & $-0.41(<0.001)$ \\
Age 1 & $-0.28(0.13)$ & $-0.44(<0.001)$ \\
Age 2 & $-0.18(1.0)$ & $-0.31(0.047)$ \\
Age 3 & $-0.24(0.63)$ & $-0.37(0.003)$ \\
Age 4+ & $-0.07(1.0)$ & $-0.18(1.0)$ \\
Density & $-0.31(0.041)$ & $-0.45(<0.001)$ \\
Biomass & $0.13(0.32)$ & $0.25(0.457)$ \\
\hline
\end{tabular}

Table V

Eel densities recorded at $\mathrm{N}$ stations in 1981 and from 1998 to 2003. Classification per age according to a normalised size-age key.

Tableau V

Densités d'anguilles mesurées sur N stations en 1981 et de 1998 à 2003. Classification par âge d'après une clé taille-âge normalisée.

\begin{tabular}{|c|c|c|c|c|c|c|}
\hline \multirow[b]{2}{*}{ Year } & \multirow{2}{*}{$\mathbf{N}$} & \multicolumn{5}{|c|}{ In river density per age (nb. $\mathrm{m}^{-2}$ ) } \\
\hline & & Age 0 & Age 1 & Age 2 & Age 3 & Age $4+$ \\
\hline 1981 & 17 & 0 & 0.01 & 0.02 & 0.03 & 0.04 \\
\hline 1998 & 19 & 0.06 & 0.26 & 0.11 & 0.09 & 0.09 \\
\hline 1999 & 19 & 0.05 & 0.20 & 0.10 & 0.08 & 0.08 \\
\hline 2000 & 19 & 0.06 & 0.22 & 0.11 & 0.08 & 0.08 \\
\hline 2001 & 19 & 0.05 & 0.21 & 0.12 & 0.09 & 0.10 \\
\hline 2002 & 19 & 0.03 & 0.18 & 0.10 & 0.08 & 0.07 \\
\hline 2003 & 19 & 0.02 & 0.12 & 0.09 & 0.06 & 0.06 \\
\hline
\end{tabular}


Electrofishing efficiency was higher in 1981 (75 $\pm 13 \%)$ than in 1998-2003 (MannWhitney test, $N=131, p<0.05)$. This result indicates that longer sectors did not reduce the fishing efficiency.

In 1981, young eels were scarce with low densities of age 0 to 2 eels in all sectors (Figure 7, Table V).

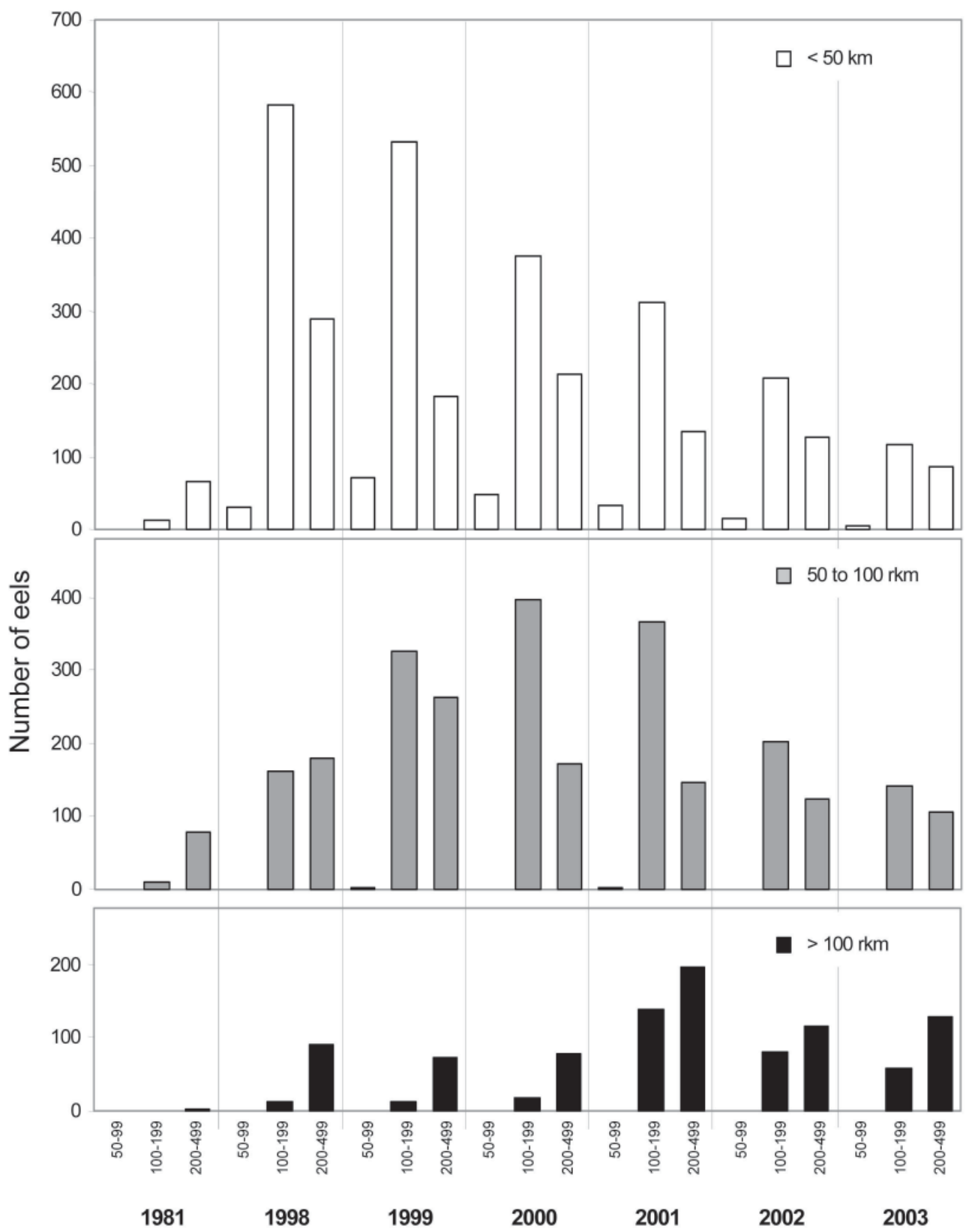

Figure 7

Comparison, by distance class, of size structures of eels sampled by electrofishing in 1981 and from 1998 to 2003.

\section{Figure 7}

Comparaison des structures de taille des anguilles échantillonnées par pêche électriques en 1981 et de 1998 à 2003 pour trois classes de distance. 


\section{Spatio-temporal trend}

From 1998 to 2003, recruitment variation was not linearly linked with abundance. In the downstream and middle stream areas, eels classified as age 1 formed between 38 and $50 \%$ of total density according to the sector and the year and accounted for most of the variation (Figure 5). In the downstream area, age 1 densities decreased regularly from a maximum value of 0.57 eels. $\mathrm{m}^{-2}$ in 1998 to a minimum of 0.11 eels. $\mathrm{m}^{-2}$ in 2003. In the middle stream area, density increased from 0.20 eels. $\mathrm{m}^{-2}$ to a maximum of 0.48 eels. $\mathrm{m}^{-2}$ in 2000 and next decreased to 0.17 in 2003. In the upstream area, the increase in density in 2001 was similar for age classes 2, 3 and $4+$. There was no significant correlation between age 0 density and recruitment of the year $(p=0.8)$. Similarly, densities of eels classified as age $1(p=0.75)$ and $2(p=0.08)$ were not correlated with shifted recruitments from 1997 and 1996. Whatever the lag, cross correlations between fluvial recruitment and densities, densities per age or densities per age and per sector, were never significant.

\section{DISCUSSION}

In the context of glass eel recruitment failure (MORIARTY and DEKKER, 1997), mirrored in both landings of the glass eel fishery (BRIAND et al., 2003) and in the trapping ladder catches (Figure 4), the construction of an estuarine eel ladder led to a large increase of the freshwater yellow eel population of the Vilaine basin (Figure 5).

\section{Fluvial recruitment}

The first step in analysing this change was to evaluate the input to the freshwater part of the Vilaine basin and the possible evolution of the Arzal dam eel passage ability since its construction in 1970.

Glass eels are recruited all year round in the Vilaine estuary, but the main run follows a modal curve from November to April (GUÉRAULT et al., 1992) with a peak centred in February (GUÉRAULT et al., 1986). They concentrate downstream from the Arzal dam where they are targeted by the commercial fishery. As long as they use STST, glass eels are unlikely to escape the fishery and exploitation rate is presumably very high (BRIAND et al., 2003). The main escapement occurs after the commercial fishery when a rise in glass eel densities is observed in the estuary (ELIE and RIGAUD, 1984; GUÉRAULT et al., 1991). Apart from the eel ladder, the only route for glass eels towards freshwater is the navigation sluice and it has always accounted for a reduced part of the recruitment because winter traffic of boats is low. At the yellow eel stage, crossing the dam is also possible through the sluice but large eels are also able to cross the gates overflow. Between 1981 and 1996, the major change has been the decline in glass eel catches from 52-209 tons in 1976-1981 to 14-21 tons in 1996-2000. No change occurred in the fishing effort or location and apart from a diminution in duration of the fishing season, its efficiency has remained stable. The escapement rate through sluice and dam overflow has probably remained unchanged.

As in 1981, very large recruitments led to a depleted glass eel migration, it can be stated that 1996 to 2003 passages through the sluice were probably negligible. Consequently, glass eel counting at the trapping ladder is a good measure of fluvial recruitment. This assertion is less clear when considering the net effect of glass eel recruitment on the yellow eel population. Indeed, post-stocking mortality was probably high during transport operations (BERG and JØRGENSEN, 1994). Post-stocking mortality was probably lower when glass eels were caught on the trapping ladder, where handling of glass eels was reduced and where migration towards freshwater was the consequence of a natural choice (Table II). In 2002 and 2003, fluvial recruitment consisted of a larger part of fished and transported glass eels and the resulting survival might have been lower than shown in Figure 4. 


\section{Effect of the Arzal eel ladder construction}

The use of eel ladders was advocated in the river Severn and Thames (APRAHAMIAN, 1986; NAISMITH and KNIGHTS, 1988; WHITE and KNIGHTS, 1997) as a method to increase eel density and production. In the Vilaine, the construction of the eel ladder allowed the passage of two large glass eel fluvial recruitments in 1996 (450 kg-1.33 million) and 1998 (700 kg-2.47 million). The re-opening of the watershed resulted in high densities $\left(>1\right.$ eels. $\mathrm{m}^{-2}$ ) in the downstream and middle stream areas two or three years after construction of the eel ladder. Densities as large as 3.2 eels. $\mathrm{m}^{-2}$ were found in 1999 and several sectors with densities $>2$ eels. $\mathrm{m}^{-2}$ were found from 1998 to 2001. Similar densities of 1 eel. $\mathrm{m}^{-2}$ have been recorded a few kilometres from the estuary in the Esva or Severn rivers (LOBÓN-CERVIÁ et al., 1995; KNIGHTS et al., 2001).

The comparison of 1981 and 1998-2000 results confirms that the Arzal eel ladder installation had an important effect on the eel population upstream from the dam. Eel densities increased six fold between 1981 and 1998. Young ages increased sharply, with densities multiplied by 29 (ages 0 and 1) and by 5 (age 2) between 1981 and 1998-2000 (Table V). The difference in density and size structure between 1981 and 1996-2000 could have resulted from a difference in station size or electrofishing method between the two studies. For example, a lesser part of shallow stretches in larger 1981's sectors could have induced a shift in both density and size composition. However, this is unlikely because on several locations, 1981 stations encompassed 1998-2000 sectors and produced less young eels even in larger sectors. In addition, both surveys were targeted for eels and used a similar method (RIGAUD, personal communication), and the electrofishing efficiency was higher in 1981.

Consequently, there has been a large increase in yellow eel density and a shift in population structure between 1981 and 1998. These changes must be analysed in light of the considerable drop in the number of recruits available for migration towards the watershed. Very large runs of glass eels, blocked by the dam had little effect on the watershed eel population. An explanation for the dominance of large-sized eels and the presence of a large biomass in 1981 is that fluvial recruitment only occurred by largesized eels having the ability to cross the dam overflow (ELIE and RIGAUD, 1984).

Other observations confirm the effect of dam and the usefulness of trapping ladders. Dams have a larger effect than distance in explaining the age composition, as densities were more correlated with the number of dams than with distance for eels of one year or older (Table IV). For example, age 1 mean density in the Arches brook (69 rkm), accessible after the crossing of four navigation dams remained low $(<0.03$ ind. $\mathrm{m}^{-2}$ ). In comparison, mean age-one densities in the Canut Sud river were up to 0.63 ind. $\mathrm{m}^{-2}$. This river was located at a similar distance (66 rkm) but accessible after the crossing of only one dam. The installation of 13 eel ladders on the Vilaine waterway in 1999 and 2000 was also followed by an increase in yellow eel densities in the upstream area in 2001 (Figure 5).

\section{Glass eel migration}

One clear result is that few ages 0 individuals were collected on tributaries, and most were from late electrofishing operations (November) and downstream sectors. As electrofishing was efficient, even at the glass eel stage, it can be concluded that glass eels did not migrate to tributaries, as confirmed by the only significant correlation found between age structure and density. They probably rested before beginning their upstream migration and remained for a while in the deep main stream, in accordance with several observations on other watersheds (MORIARTY, 1986; APRAHAMIAN, 1988; NAISMITH and KNIGHTS, 1988; LOBÓN-CERVIÁ et al., 1995). 


\section{Density dependent effects}

Within a distance class, spatial variation in density and biomass was larger than yearly variation. Eel habitat partitioning varied according to habitat and the resulting variability explains the lack of significance in temporal trend (LAFFAILLE et al., 2003). Seasonal fluctuations in eel densities probably occurred (RASMUSSEN, 1983; MORIARTY, 1986; BARAK and MASON, 1992; LOBÓN-CERVIÁ et al., 1995) but had a limited effect when compared to habitat variability, as the sampling period remained in late summer.

Even if not significant, clear temporal trends were observed for separate distance sectors and the age structure was significantly modified in all sectors (Figures $5,6,7$ ). The relation between yellow eel population and fluvial recruitment was less clear. From 1998 to 2000 the lowest age-1 density observed in 1999 corresponded to the largest run in 1998 (Table V). The large variability in growth of eels (MOUNAIX, 1992) and the variation in cohort strength, might have misled the interpretation derived from a constant size-age key. But the variation in growth is less important at age 1 than after several years and although density-per-age must be analysed with caution, the size distribution was similar for all years (Figure 7).

The first explanation for the diminution of age- 1 eel densities in downstream sectors could be the drop in fluvial recruitment. But the drop in density was delayed by two years in middle stream sectors.

A colonisation process combining density-dependent mortality and migration could explain the shift in age composition and density. A progressive migration to the periphery of saturated zones located in the downstream area would explain synchronous middle stream increase and downstream decrease in densities. It is possible to speculate that an increase in density was observed from 1996 to 1998 in the downstream sectors, and that reopening of the watershed resulted in very large densities of young eels, similar to those observed in 1999 in middle stream sectors. From 1998, watershed saturation would have increased mortality of young eels entering the downstream-saturated rivers because of competition and cannibalism behaviours (SINHA and JONES, 1967; KNIGHTS, 1987; LAMOTHE et al., 2000). A replacement by larger eels would not be apparent in the shallow sectors, because the foraging area might not coincide with the resting place located in deeper sectors of the tributary (LAFFAILLE et al., 2004), as niche breadth expands with increasing size of eels (BARAK and MASON, 1992). These observations would indicate that downstream and middle stream sectors reached carrying capacity in 1998 and 2000. In the Severn river, sites with similar densities ranging from 0.12 to 1.14 eels. $\mathrm{m}^{-2}$ and eel biomass from 2.56 to $25.24 \mathrm{~g} \cdot \mathrm{m}^{-2}$ showed no relationship between growth rate and stock size (APRAHAMIAN, 2000). The author explained this result by suggesting that all sites were at or below carrying capacity. The results observed in this study would argue in favour of the first assertion. It is also possible to speculate that density-dependent effects act more on density-dependent migration and mortality than growth rate.

High proportions of age- 1 eels were observed in rivers Arz, Canut Sud and Aron, migrating from 1999 to 2000 to reach the upper sectors of the tributaries. Later in 2001, the same increase was noticed in the Canut Nord (Figure 1). These observations are consistent with a wave form of migration associated with migration rates probably larger than $50 \mathrm{~km}$ per year and with a density peak observed inland. This result contrasts with the observations on Great Britain rivers where no wave form migration was observed (IBBOTSON et al., 2002). However, the observed colonization doesn't need to be explained by an orientated massive run at the yellow eel stage because it can be accounted for by the sudden change in fluvial recruitment. The rapidity of freshwater colonization when compared to values of 10-20 km. $\mathrm{y}^{-1}$ (APRAHAMIAN, 1988; MANN and BLACKBURN, 1991) could be explained by the gentle slope of the downstream freshwater reach and the absence of dams in the downstream reach. 


\section{Remaining uncertainties}

The following points must be stressed:

- The sampling of shallow areas in narrow tributaries using the point sampling method has probably led to overestimates of real densities because eels of small size concentrated in those habitats.

- The variability in eel abundance was large and the temporal trends used to argue for saturation were not significant. This is probably linked with a problem of patchy distribution of eels, particularly when focusing on migrating individuals, resting for a while in favourable habitats during the course of their ascent.

- No data was available for larger and deeper stream sectors.

- It was not possible to assess the respective effects of fluvial recruitment decline and density-dependent mortality in the overall decline of yellow eel densities.

- Because the population consisted mainly of small eels shortly after re-opening of the dam, density-dependent mortality could have been lower than if settled populations had been present.

\section{Considerations on an escapement target for the glass eel fishery}

The previous considerations question mainly the interpretations concerning density-dependent mortalities and the absolute values of eel densities and biomass. The changes brought by the construction of the eel ladder remain clear and the examination of five years of data has changed little of the conclusions expressed after only two years (BRIAND et al., unpublished). Consequently, the following statements can be considered as sound: (1) The escapement from the glass eel fishery is very low, ranging between 0.22 and 2.47 million of glass eels per year, and fluvial recruitment was only 1 to $5 \%$ of the commercial fishery catch (BRIAND et al., 2003). (2) This escapement led to the colonisation of the entire basin, with large densities and a possible saturation in the downstream and middle stream areas.

An adaptive management (LEE, 1993) can be proposed for eels, in the absence of definite knowledge of the effect of management measures. This management allows short-term feedback in the management system (DEKKER, 2004). It must include the uncertainties and propose somewhat strict rules to ascertain the reaching of a target. The preliminary escapement target chosen for the Vilaine glass eel fishery was the largest recruitment observed from 1996, i.e. $700 \mathrm{~kg}$ or 2.47 millions of glass eels. It was chosen rather arbitrarily in 1998 and was later confirmed as an escapement target allowing large densities far upstream from the estuary, and possibly saturating the most downstream sectors. This target corresponds to 240 glass eel or $70 \mathrm{~g}$ per $\mathrm{km}^{2}$ of watershed area. It also corresponds to $0.42 \mathrm{~kg}$ or 1500 glass eel per ha of water surface. It is higher than the stocking rate of $0.1 \mathrm{~kg} / \mathrm{ha}$ proposed for still and running waters (MORIARTY and DEKKER, 1997).

This target is specific to the Vilaine because it is calculated at a dam where glass eels accumulate in the estuary. It would not necessarily apply to longer estuaries or at trapping ladders located farther from the accumulation point because in these cases it would be necessary to account for the negative exponential distribution of yellow eel populations and the short penetration of glass eel stages. It could however be used in exploitation rate models as a preliminary target of escapement from the glass eel fisheries to watersheds area including estuaries.

\section{Conclusion advocating eel ladder equipment}

Installing an eel ladder in the tidal estuary of the Vilaine was proposed as early as 1984 by ELIE and RIGAUD (1984) as compensation to the construction of a blocking dam. 
The results from this study doubtless show that this eel ladder had a large effect on the eel population upstream, and that the other passes installed on the waterways helped increasing the population at a large distance from the estuary.

\section{ACKNOWLEDGMENTS}

This work was initiated early and we would first like to thank Drs ELIE and RIGAUD for the description of the effect of the Arzal dam on the eel population and for providing the historical reference for electrofishing data. This study was supported by the Conseil Supérieur de la Pêche, the Loire-Bretagne Water Agency, European Union, as well as various national and regional funds. We thank J.P. PORCHER and D. BOUSSION for their help in setting up electrofishing stations, the Conseil Supérieur de la Pêche brigades for conducting electrofishing operations, and Brice Sauvaget for his help in data computing. We also thank François CARON and Doug DIXON for their valuable advice on a preliminary manuscript, and two anonymous reviewers for their helpful comments.

\section{REFERENCES}

AOYAMA J., 2003. Origin and Evolution of the Freshwater Eels, Genus Anguilla. In: Eel Biology (eds K. AIDA, K. TSUKAMOTO and K. YAMAUCHI), pp. 19-30. Springer, Tokyo.

APRAHAMIAN M.W., 1986. Eel (Anguilla anguilla L.) production in the River Severn, England. Pol Arch. Hydrobiol., 33, 373-389.

APRAHAMIAN M.W., 1988. Age structure of eel, Anguilla anguilla (L.), populations in the River Severn, England, and the River Dee, Wales. Aquac. Fish. Manag., 19, 365376.

APRAHAMIAN M.W., 2000. The growth rate of eel in tributaries of the lower River Severn, England, and its relationship with stock size. J. Fish. Biol., 56, 223-227.

BAISEZ A., 2001. Optimisation des suivis des indices d'abondances et des structures de taille de l'anguille européenne (Anguilla anguilla, L.) dans un marais endigué de la côte Atlantique : Relation espèce-habitat. Thèse de troisième cycle, Université de Toulouse III, CEMAGREF, Toulouse.

BARAK N.A.E., MASON C.F., 1992. Population density, growth and diet of eels, Anguilla anguilla L., in two rivers in eastern England. Aquac. Fish. Manag., 23, 59-70.

BERG R., JØRGENSEN J., 1994. Stocking experiment with 0+ eels (Anguilla anguilla L.) in Danish streams: post stocking movements, densities and mortality. In: Rehabilitation of freshwater fisheries (ed I.G. COWX), pp. 314-325. Fishing News Books, Oxford.

BERTIN L., 1951. Les anguilles. Variation, croissance, euryhalinité, toxicité, hermaphrodisme juvénile et sexualité, migrations, métamorphoses, p. 188. Payot, Paris.

BRIAND C., FATIN D., FEUNTEUN E., FONTENELLE G., 2003. Estuarine and fluvial recruitment of European glass eel in a fished Atlantic estuary. Fish. Man. Ecol., 10, 377-384.

CASTELNAUD G., 2000. Localisation de la pêche, effectifs de pêcheurs et production par pêche des espèces amphihalines dans les fleuve français. Bull. Fr. Pêche Piscic., 357/358, 439-460.

COWX I.G., LAMARQUE P., eds., 1990. Fishing with electricity, applications in freshwater fisheries management, p. 248. Blackwell, Oxford. 
DEKKER W., 2004. Slipping through our hands- Population dynamics of the european eel. Phd thesis $186 \mathrm{p}$.

ELIE P., RIGAUD C., 1984. Étude de la population d'anguilles de l'estuaire et du bassin versant de la Vilaine: examen particulier de l'impact du barrage d'Arzal sur la migration anadrome (civelles), proposition d'amélioration du franchissement de cet obstacle. Cemagref/Université de Rennes, Rennes.

FEUNTEUN E., 1994. Le peuplement piscicole du marais littoral endigué de BourgneufMachecoul (France Loire-Atlantique). Approche méthodologique pour une analyse quantitative de la distribution spatiale du peuplement piscicole et de la dynamique de certaines de ses populations. Thèse $3^{\text {ème }}$ cycle, Université Rennes I, $240 \mathrm{p}$.

FEUNTEUN E., ACOU A., LAFAILLE P., LEGAULT A., 2000. European eel: prediction of spawner escapement from continental population parameters. Can. J. Fish. Aquat. Sci., 57, 1627-1635.

FEUNTEUN E., LAFFAILLE P., ROBINET T., BRIAND C., BAISEZ A., OLIVIER J.-M., ACOU A., 2003. A Review of Upstream Migration and Movements in Inland Waters by Anguillid Eels: Toward a General Theory. In: Eel biology (eds K. AIDA, K. TSUKAMOTO and K. YAMAUCHI), pp. 181-190. Springer, Tokyo.

GASCUEL D., 1986. Flow carried and swimming migration of the glass eel (Anguilla anguilla) in the tidal area of a small estuary on the French Atlantic coast. Helgolander Meeresun., 40, 321-326.

GASCUEL D., 1987. La civelle d'anguille dans l'estuaire de la Sèvre Niortaise : biologie, écologie, exploitation, rapport global. Publications Département Halieutique, École Nationale Supérieure Agronomique, Rennes.

GLOVA G.J., 2001. Effects of the presence of subadult longfinned eels (Anguilla dieffenbachii) on cover preferences of juvenile eels (Anguilla spp.) in replicate channels. N. Z. J. Mar. Freshwat. Res., 35, 221 - 233.

GLOVA G.J., 2002. Density effects on juvenile shortfinned eel (Anguilla australis) cover preferences in replicate channels. N.Z. J. Mar. Freshwat. Res., 36, 283-290.

GUÉRAULT D., BEILLOIS P., DÉSAUNAY Y., DOREL D., 1986. Variations de l'abondance de la civelle au travers des données de production secteurs Loire et Vilaine. Vie Milieu, 36, 237-241.

GUÉRAULT D., PROUZET P., DÉSAUNAY Y., BEILLOIS P., 1991. The recent evolution of the glass-eel immigration in three French Atlantic estuaries. In Eifac working party on eel, p. 18, Dublin (Ireland).

GUÉRAULT D., LECOMTE-FINIGER R., DÉSAUNAY Y., BIAGANTI-RISBOURG S., BEILLOIS P., GRELLIER P., 1992. Glass eels arrivals in the Vilaine estuary (Northern Bay of Biscay) in 1990: demographic features and early life history. Irish Fish. Invest., 36, 5-14.

IBBOTSON A., SMITH J., SCARLETT P., APRAHAMIAN M.W., 2002. Colonisation of freshwater habitat by the European eel Anguilla anguilla. Freshwater Biol., 47, 1696-1706.

KNIGHTS B., 1987. Agonistic behaviour and growth in the European eel, Anguilla anguilla L., in relation to warm-water aquaculture. J. Fish Biol., 31, 265-276.

KNIGHTS B., BARK A., BALL M., WINTER E., DUNN S., 2001. Eel and Elver stock in England and Wales - status and management options, Rep. No. R\&D technical report $N^{\circ}$ W248. Environment Agency, Bristol.

LAFFAILLE P., BAISEZ A., RIGAUD C., FEUNTEUN E., 2004. Habitat preferences of different European eel size classes in a reclaimed marsh: a contribution to species and ecosystem conservation. Wetlands, 24, 642-651. 
LAFFAILLE P., FEUNTEUN E., BAISEZ A., ROBINET T., ACOU A., LEGAULT A., LEK S., 2003. Spatial organisation of the European eel (Anguilla anguilla, L.) in a small catchment. Ecol. Freshwat. Fish., 12, 254-254.

LAMARQUE P., 1976. Types de courant électrique à utiliser pour la capture optimale des poissons principalement les anguilles. La Pisciculture Française, 47, 30-37.

LAMOTHE P.J., GALLAGHER M., CHIVERS D.P., MORING J.R., 2000. Homing and movement of yellow-phase American eels in freshwater ponds. Environ. Biol. Fish., 58, 393-399.

LEE K.L., 1993. Compass and Gyroscope. Integrating science and politics for the environment, p. 243. Island Press, Washington.

LEGAULT A., 1986. Distribution du peuplement d'anguille (Anguilla anguilla L.) à l'échelle d'un bassin versant: étude en Sèvre Niortaise. Vie Milieu, 36 (4), 261-265.

LEGAULT A., 1992. Étude de quelques facteurs de sélectivité de passes à anguilles. Bull. Fr. Pêche Piscic., 325, 83-91.

LEGAULT A., 1996. Colonization dynamics of a catchment area by eel. Characterization of migrating populations in a free access river. In Ecohydraulique 2000, Québec.

LOBÓN-CERVIÁ J., UTRILLA C.G., RINCÓN P.A., 1995. Variations in the population dynamics of the European eel Anguilla anguilla (L.) along the course of a Cantabrian river. Ecol. Freshwat. Fish, 4, 17-27.

MANN R.H.K., BLACKBURN J.H., 1991. The biology of the eel Anguilla anguilla (L.) in an English chalk stream and interactions with juvenile trout Salmo trutta L. and salmon Salmo salar L. Hydrobiologia, 218, 65-76.

MCCLEAVE J.D., WIPPELHAUSER G., 1987. Behavioral aspects of selective tidal stream transport in juvenile American eel. Am. Fish. Soc. Symp., 1, 138-150.

MORIARTY C., 1986. Riverine migration of young eels Anguilla anguilla (L.). Fish. Res., 4, 43-58.

MORIARTY C., DEKKER W., 1997. Management of the European eel. Fish. Bull., 15, 1110.

MOUNAIX B., 1992. Intercalibration et validation des méthodes d'estimation de l'âge de l'Anguille européenne (Anguilla anguilla, L.). Application au bassin versant de la Vilaine, Bretagne. Thèse Ingénieur, École nationale Supérieure Agronomique de Rennes, Rennes, $146 \mathrm{p}$.

NAISMITH I.A., KNIGHTS B., 1988. Migrations of elvers and juvenile European eels, Anguilla anguilla L., in the River Thames. J. Fish. Biol., 33, 161-175.

RASMUSSEN G., 1983. Recent investigations on the population dynamics of eels (Anguilla anguilla L.) in some Danish streams. In Proc. 3rd Brit. Freshw. Fish. Conf., pp. 7177, Liverpool.

SINHA V.R.P., JONES J.W., 1967. On the age and growth of the freshwater eel (Anguilla anguilla). J. Zool., 153, 99-117.

SMOGOR R.A., ANGERMEIER P.L., GAYLORD C.K., 1995. Distribution and abundance of American eels in Virginia streams: test of null models across spatial scales. Trans. Am. Fish. Soc., 124.

TESCH F.W., 2003. The eel (ed J. E. THORPE), pp. 407. Blackwell Publishing, London.

TZENG W.N., 2003. The Processes of Onshore Migration of the Japanese Eel Anguilla japonica as Revealed by Otolith Microstructure. In Eel biology (eds K. AIDA, K. TSUKAMOTO and K. YAMAUCHI), pp. 181-190. Springer, Tokyo. 
VILTER V., 1944. Conditionnement physique du «cordon " chez les civelles migratrices. C. R. Soc. Biol., 655-656.

VØLLESTAD L.A., JONSSON B., 1988. A 13-year study of the population dynamics and growth of the European eel Anguilla anguilla in a Norwegian river: evidence for density-dependent mortality, and development of a model for predicting yield. J. Anim. Ecol., 57, 983-997.

WHITE E., KNIGHTS B., 1997. Dynamic of upstream migration of the European eel, Anguilla anguilla (L.), in the River Severn and Avon, England, with special reference to the effect of man-made barriers. Fish. Man. Ecol., 4, 311-324.

WILLIAMSON G.R., 1987. Vertical drifting position of glass eel, Anguilla rostrata, off Newfoundland. J. Fish Biol., 31, 587-588.

WIPPELHAUSER G., MCCLEAVE J.D., 1987. Precision of behavior of migrating juvenile American eels (Anguilla rostrata) utilizing selective tidal stream transport. J. Cons. Perm. Int. Explor. Mer., 44, 80-89.

ZALEWSKI M., COWX I.G., 1990. Factors affecting electric fishing efficiency. In Fishing with electricity, applications in freshwater fisheries management (eds I.G. COWX and P. LAMARQUE), pp. 89-111. Blackwell, Oxford. 